\title{
The influence of repeated prescribed fire on decomposition and nutrient release in uneven-aged loblolly-shortleaf pine stands
}

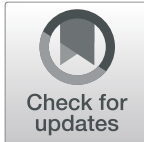

Hal O. Liechty ${ }^{1 *}$ (D) and Michele Reinke ${ }^{2}$

\begin{abstract}
Background: Repeated use of prescribed fire in Southern US pine stands has the potential to alter litter quality as well as forest floor mineralization, which may reduce nutrient availability. There are few studies that have investigated the effects of prescribed fire on litter decomposition in stands with frequent, partial harvests. To better understand the effects of the long-term use of prescribed fire coupled with periodic harvesting, we monitored foliar litter mass loss and nutrient dynamics in three loblolly pine (Pinus taeda L.)-shortleaf pine (Pinus echinata Mill.) stands located in southeastern Arkansas, USA. A reciprocal transplant method and the litterbag technique were used to determine the effects of litter source (litter quality) and litter location (environmental conditions) on decomposition.

Results: Long-term use of prescribed fire in periodically harvested stands had minimal influence on mass loss and nutrient dynamics. The proportion of foliar litter remaining after approximately 16 months did not significantly differ by litter source or location. Decay constants associated with litter incubated during the first 30 days of the study differed significantly by litter source, but thereafter were similar. Initial concentrations of phosphorus (P), potassium (K), calcium (Ca), and magnesium (Mg) were 13 to 22\% greater for litter originating from the burn than for litter originating from the control treatment, but differences in nutrient concentrations were not found to alter decomposition or nutrient dynamics. Thirteen percent more $\mathrm{K}$ was lost from litter originating from the burn compared to litter originating from the control treatment, but losses of other nutrients did not differ between litter sources. Soil and forest floor environmental conditions did not differ between treatment locations, which likely contributed to the similar decomposition rates in the two treatment locations. The rapid growth of understory and the maintenance of similar canopy conditions as a result of harvesting were likely responsible for the similarity in environmental conditions.

Conclusions: Repeated dormant season prescribed fire in these loblolly-shortleaf pine stands did not appear to have a substantial influence on mass loss or nutrient release from litter. Land managers who utilize prescribed fire with periodic harvesting in relatively mesic upper Gulf Coastal Plain pine forests likely will not alter litter decomposition or nutrient dynamics.
\end{abstract}

Keywords: decay constants, foliar litter quality, nutrient dynamics, periodic harvesting, Pinus echinata, Pinus taeda, reciprocal transplant method

\footnotetext{
* Correspondence: liechty@uamont.edu

'Arkansas Forest Resource Center, 110 University Court, Monticello, AR 71656,

USA

Full list of author information is available at the end of the article
} 


\section{Resumen}

Antecedentes: El uso repetido de quemas prescriptas en rodales de pino en el sur de los EEUU tiene el potencial de alterar la calidad de la broza como así también la mineralización del suelo, lo que puede reducir la disponibilidad de nutrientes. Hay muy pocos estudios que han investigado los efectos de las quemas prescriptas en la descomposición de la broza en rodales con cosechas parciales y frecuentes. Para comprender mejor los efectos del uso a largo plazo de quemas prescriptas acopladas con cosechas periódicas, monitoreamos la pérdida de broza proveniente de acículas y la dinámica de nutrientes en tres rodales de pino taeda (Pinus taeda L.) y pino de hoja corta (Pinus echinata Mill.) ubicados en el sudeste de Arkansas (EEUU). El método de trasplantes recíprocos y la técnica de las bolsas de broza fueron usados para determinar los efectos de la fuente de broza (calidad de broza) y la ubicación de la broza (condiciones ambientales) en la descomposición

Resultados: El uso prolongado de quemas prescriptas en rodales cosechados periódicamente tuvo una influencia mínima en la pérdida de masa de broza y en la dinámica de nutrientes. La proporción de broza de acículas que permaneció después de 16 meses no difirió significativamente en función de la fuente o ubicación. Las constantes de caída asociadas con la broza incubada durante los primeros 30 días de estudio difirieron significativamente en cuanto a la fuente, pero luego fueron similares. Las concentraciones iniciales de fósforo $(\mathrm{P})$, potasio $(\mathrm{K})$, y magnesio $(\mathrm{Mg})$ fueron del 13 al $22 \%$ más alta para la broza originada por quemas prescriptas que las del control sin quemar, aunque las diferencias en la concentración de nutrientes no alteraron la descomposición o la dinámica de nutrientes. Un trece por ciento más de $\mathrm{K}$ fue perdido en la broza originada en las quemas comparada con el tratamiento de control, aunque la pérdida de otros nutrientes no difirió entre las diferentes fuentes de broza. El suelo y las condiciones ambientales del suelo forestal no difirieron entre las ubicaciones de los tratamientos, lo cual probablemente contribuyó a obtener tasas de descomposición similares en las dos ubicaciones de los tratamientos. El rápido crecimiento del sotobosque y el mantenimiento de condiciones de doseles similares como resultado de las cosechas, fueron aparentemente responsables de las similitudes en las condiciones ambientales.

Conclusiones: Las quemas repetidas durante la estación de dormición en estos rodales de pino taeda-pino de hoja corta no parecen tener una influencia substancial en la pérdida de broza o en la liberación de nutrientes de la broza. Los manejadores de tierras que utilizan quemas prescriptas con cosechas periódicas en ambientes relativamente mésicos en bosques de pino de las Planicies Altas Costeras del Golfo (Gulf Coastal Plains) es probable que no alteren la descomposición de la broza o la dinámica de nutrientes.

\section{Background}

Prescribed fire in the southern United States is used to restore and maintain fire-dependent Southern pine ecosystems (Van Lear 2000; Haines et al. 2001; Stanturf et al. 2002; Ryan et al. 2013) and promote habitat for important wildlife species (Haines et al. 2001). Restoration and maintenance of these communities requires application of prescribed fire at an appropriate return interval to promote species diversity, establish fire-dependent species, and generate suitable fuel loads (Mitchell et al. 2006). In addition, restoration efforts frequently require harvesting to simulate natural disturbances as well as to remove hardwoods that encroach stands during periods of fire exclusion (Mitchell et al. 2006; Guldin 2007).

Repeated application of fire in Southern pine stands has been found to increase the carbon $(\mathrm{C})$ :nitrogen $(\mathrm{N})$ ratios in the forest floor (McKee 1982; Bell and Binkley 1989; Binkley et al. 1992; Liechty and Hooper 2016). Changes in litter C:N ratios in these forests with prescribed burning may affect processes such as $\mathrm{N}$ mineralization. Bell and Binkley (1989) found that increased $\mathrm{C}: \mathrm{N}$ ratios associated with fire return intervals of two and four years tended to decrease forest floor $\mathrm{N}$ mineralization. Litter decomposition rates have also been found to be well correlated with litter $\mathrm{N}$ content and C:N ratios (Taylor et al. 1989; Enríquez et al. 1993; Zhang et al. 2008). However, differences in litter N content and C:N ratios as a result of fertilization (Sanchez 2001) or repeated prescribed fire application (Ficken and Wright 2017) have been reported to have minimal impacts on decomposition rates within pine stands in the southern United States. Although Sanchez (2001) found little impact of litter quality on decomposition, he did find that litter quality and chemistry affected nutrient dynamics within decomposing loblolly pine (Pinus taeda L.) litterfall.

Alteration of litter processes by prescribed fire can also occur due to changes in microclimate of the forest floor and soil (Raison et al. 2009). Long-term use of prescribed fire in Southern pine stands in some instances has been found to alter soil-water holding capacity and thus reduce soil moisture (Carter and Foster 2004). 
Ficken and Wright (2017) observed warmer soil surface temperatures in longleaf pine (Pinus palustris Mill.) stands that were annually burned compared to stands where fire was not included in management prescriptions. However, short-term litter decomposition rates in this study were unaffected by these changes in soil temperature. Gurlevik et al. (2003) found that a reduction in decomposition rates corresponded to an increase in litter temperature and a reduction of litter moisture following removal of competing vegetation from a 14-year-old loblolly pine stand. Removal of vegetation by fire during restoration could potentially also alter litter microclimate and thus decomposition.

Few studies have evaluated the result of long-term prescribed fire on soil or forest floor in Southern pine stands that are managed with periodic, partial harvesting regimes. Liechty and Hooper (2016) compared soils and forest floor in uneven-aged loblolly-shortleaf pine (Pinus echinata Mill.) stands managed with single-tree selection and either periodic dormant season prescribed fires (8 fires during 18 years) or fire exclusion. The stands with fire exclusion had higher forest floor mass and lower forest floor C:N ratios than stands with prescribed burning but similar surface mineral soil nutrient concentrations. To better understand the effects of fire in the stands utilized in the study reported by Liechty and Hooper (2016), we assessed rates of foliar litter mass loss, nutrient dynamics in the decomposing litter, and foliar litter quality in the stands that were managed with and without periodic prescribed fire.

\section{Methods}

\section{Study location and description}

The study was conducted within three 16 ha stands located in the Crossett Experimental Forest in Ashley County, Arkansas, USA $\left(33.03^{\circ},-91.93^{\circ}\right)$. The stands are located approximately $53 \mathrm{~m}$ above sea level with only minor changes of topography. Daily temperatures during the growing and dormant seasons average $22{ }^{\circ} \mathrm{C}$ and $11{ }^{\circ} \mathrm{C}$, respectively (USDA 1979). Soils within the three stands are dominated by a Bude silt loam, which is classified as a Glossaquic Fragiudalf, has an impervious layer at depths of 45 to $100 \mathrm{~cm}$, and is somewhat poorly drained. The overstory and midstory at the time of the study were dominated by loblolly and shortleaf pine. Sapling-sized trees $(0.6 \mathrm{~cm} \geq$ diameter at breast height $[\mathrm{dbh}] \leq 8.9 \mathrm{~cm})$ in the midstory and understory included loblolly pine, sweetgum (Liquidambar styraciflua L.), southern red oak (Quercus falcata Michx.), American holly (Ilex opaca Ait.), and water oak (Quercus nigra L.) (Cain et al. 1998; Liechty and Hooper 2016).

\section{Study design}

Beginning in 1980, each stand was utilized to assess the effect of overstory basal area retention and dormant season prescribed fire on pine regeneration. At this time, the stands were separated into four 4 ha burn interval treatments. Two of these treatments, the control (no fire) and burn treatment (1- to 4-year fire frequency), were used in our study to assess the effect of prescribed fire combined with periodic harvesting on litter decomposition. A total of eight dormant season prescribed fires were set in the burn treatment prior to the initiation of the litter decomposition study in February of 2000. Information on the date of each prescribed fire, fire intensity, fuel moistures, etc., can be found in Cain (1993) as well as Cain and Shelton (2002). The last prescribed fire (27 Oct 1998) had fine fuel moistures of 13\%, fire line intensities (calculated from ocular estimates of flame length) between 20 and $346 \mathrm{~kW} \mathrm{~m}^{-1}$, wind speeds averaging $2 \mathrm{~km} \mathrm{hr}^{-1}$, and was considered to be low intensity (Cain and Shelton 2002).

In 1980, the basal area of merchantable-size trees $(\mathrm{dbh}>8.9 \mathrm{~cm})$ in each 4 ha treatment area ranged between 18.3 and $28.7 \mathrm{~m}^{2} \mathrm{ha}^{-1}$. In 1982, each 4 ha treatment was divided into four 1 ha plots and thereafter managed using an uneven-aged, single-tree selection method with one of four different residual basal areas (Cain 1993; Cain and Shelton 2002). Our decomposition study occurred in the 1 ha plot managed at $14 \mathrm{~m}^{2} \mathrm{ha}^{-1}$. Singletree selection harvests occurred in the summer or fall of 1982, 1987, 1992, and 1997. Prior to the first harvest, all living hardwoods with groundline diameters of $>2.5 \mathrm{~cm}$ were injected with Tordon 101R (Dow Agrosciences LLC, Indianapolis, Indiana, USA; $0.03 \mathrm{~kg} \mathrm{l}^{-1}$ of picloram and $0.12 \mathrm{~kg} \mathrm{l}^{-1}$ 2,4-D) in the spring of 1981 in both the burn and control treatment plots. In addition, Arsenal AC herbicide (BASF Corporation, Florham Park, New Jersey, USA; $0.42 \mathrm{~kg} \mathrm{ha}^{-1}$ active ingredient, imazapyr) and Accord (Dow Agrosciences LLC; $1.68 \mathrm{~kg} \mathrm{ha}^{-1}$ active ingredient, glyphosate) was broadcast by rubber-tired skidders in the control treatment during September 1991 to reduce hardwood competition.

\section{Litter decomposition}

The litterbag method (Mellilo et al. 1982; Lockaby et al. 1995) was used to assess the effect of the litter source (control and burn) and litter location (control and burn) on litter decomposition. The litterbags were made by using two $30 \mathrm{~cm} \times 30 \mathrm{~cm}$ nylon mesh sheets. The tops of the bags were made with a $5 \mathrm{~mm}$ mesh sheet and the bottoms with a $2 \mathrm{~mm}$ mesh sheet. This combination of mesh sizes allowed access by invertebrates while minimizing litter loss.

In the fall of 1999, fresh loblolly pine litterfall was collected using elevated litter collectors or tarps placed on the soil surface. Accumulated litter was collected biweekly from October to December and dried at $45{ }^{\circ} \mathrm{C}$ for 24 hours. Loblolly pine fascicles 
were removed from the collected litterfall and pooled by litter source (control or burn treatment). Litter was stored at room temperature and humidity until the litterfall collection was completed. Foliar litter from a given treatment was then thoroughly mixed after the final collection. Six samples were collected from each pool of control and burn litter and dried at $70{ }^{\circ} \mathrm{C}$ for 24 hours to determine moisture content and to use for chemical analysis. A total of 252 bags were each filled with $20.0 \mathrm{~g}$ of litter. Half of the bags (126) were filled with litter collected from the control treatment and the other half were filled with litter from the burn treatment.

To provide locations for litterbag placement, three $4 \mathrm{~m} \times 4 \mathrm{~m}$ subplots were established in each treatment plot on 24 Feb 2000. Subplots were located at least $10 \mathrm{~m}$ from the 1 ha treatment plot border but outside a $40 \mathrm{~m} \times 40 \mathrm{~m}$ interior plot used for vegetation sampling. One subplot was located along each of the north, west, and south portions of the 1 ha treatment plot. Two adjacent $4 \mathrm{~m} \times 0.5 \mathrm{~m}$ wide strips were trimmed of all vegetation within each subplot to allow bags to be located on the litter surface. Seven bags filled with litter from the burn treatment were located along one of the strips while seven bags from the control treatment were located along the other strip. Bags were placed on the forest floor and then fastened to the ground on each corner using pin flags. One litterbag from each litter source was collected from each subplot in a treatment plot on each of seven dates: 10 Mar 2000, 25 Mar 2000, 26 Apr 2000, 27 Jul 2000, 26 Sep 2000, 5 Jan 2001, and 10 Jun 2001. This corresponded to incubation periods of 15, 30, 62, 154, 215, 316, and 472 days. Bags were transported in individual plastic bags to the laboratory and stored at $4{ }^{\circ} \mathrm{C}$ until they were processed.

\section{Laboratory processing and analysis}

Litter in the retrieved litterbags was inspected and foreign material was removed (soil, etc.) when possible. This litter was weighed to the nearest $0.01 \mathrm{~g}$ for all collection dates except 10 Mar 2000. Litter was dried and then weighed again to the nearest $0.01 \mathrm{~g}$. Moisture contents of litter were calculated for all collection dates except 10 Mar 2000. All litter was ground to pass through a $1 \mathrm{~mm}$ sieve after drying for chemical analysis.

Concentrations of phosphorus (P), potassium (K), calcium $(\mathrm{Ca})$, and magnesium $(\mathrm{Mg})$ were determined using inductance coupled plasma analysis following a perchloric acid digestion for the plant material (Alder and Wilcox 1985). A Leco CN analyzer (Leco, St. Joseph, Michigan, USA) was used to determine $\mathrm{C}$ and $\mathrm{N}$ content by combustion for plant material. Lignin, cellulose, and hemicellulose concentrations were determined for litter samples prior to bag deployment as well as for samples incubated for 15, 215, and 472 days. These analyses were limited to these three dates due to a lack of funds. Lignin was measured as the sum of ash-free acidinsoluble lignin (Klason lignin) and acid-soluble lignin fractionated using a two-step acid hydrolysis procedure (Sluiter et al. 2008). Acid-insoluble lignin was determined gravimetrically. Acid-soluble lignin as well as cellulose and hemicellulose were determined using high $\mathrm{pH}$ anion-exchange chromatography with pulsed amperometric detection (Davis 1998).

Loss on ignition was determined for all samples using the methods of Ball (1964). Triplicate $1.00 \mathrm{~g}$ samples from each litter sample were heated to $350{ }^{\circ} \mathrm{C}$ for 18 hours, cooled, and then weighed. The ash content of the samples was used to report litter mass and nutrient concentrations on an ash-free basis (Karberg et al. 2008). Mass and nutrient contents of the litter collected from the litterbags were compared to that of the samples collected prior to litterbag installation to calculate proportion mass or nutrient content remaining after each incubation period.

\section{Microclimate}

Air and litter temperatures were monitored at two locations in each of the subplots established in each block and burning treatment combination. Air temperatures were determined at $10 \mathrm{~cm}$ above the forest floor using Onset Optic Stowaway temperature sensors (Onset Computer Corporation, Bourne, Massachusetts, USA) attached beneath an insulated $30 \mathrm{~cm}^{2}$ wooden heatshield. Litter temperatures were monitored by inserting Onset Stowaway Tidbit XT sensors (Onset Computer Corporation) in two litterbags in each subplot. Both air and litter temperatures were logged on an hourly basis starting in March following the installation of the litterbags until $15 \mathrm{Feb}$ 2001. Temperature values were summarized on a monthly time interval. Mineral soil moisture was determined gravimetrically to a depth of $3 \mathrm{~cm}$ periodically in each subplot. Five mineral soil cores $(2.54 \mathrm{~cm}$ in diameter) were collected in each subplot, placed in plastic bags, and returned to the laboratory. Moisture content of these soils was determined by drying at $105{ }^{\circ} \mathrm{C}$ for 24 hours. Samples were collected on an approximate 2- to 3-week interval after litterbag deployment until January 2001. Soil moisture was collected on a monthly or bimonthly schedule thereafter, until the last measurement in June 2001.

\section{Statistical analysis}

Mass loss of the decomposing litter in the bags was analyzed using an exponential decay model (Olson 1963) 
and by determining a decay constant $(k)$. The model was of the following form:

$$
X=X_{0} e^{-\mathrm{kt}}
$$

where $t$ equals time in years, $X$ is the mass in grams at a given time $t$, and $X_{0}$ is the initial mass at time 0 . The overall decay rate constants $\left(k_{\mathrm{o}}\right)$ for the entire duration of the study were calculated using nonlinear regression for each stand, litter source, and litter treatment location. The regression was performed using each set of data (all collection dates) from a subplot. These rate constants were used to assess differences in the decay rates between litter locations and sources. Decay constants $(k)$ for each individual collection date were also calculated by solving Equation 1 for each litter sample that was collected on a given date. Calculations of decay constants for each collection date were similar to the methods used by King et al. (1997) and Sanchez (2001). This information was used to assess differences in decomposition rates for litter sources, treatment locations, and incubation periods.

Independent $t$-tests were used to compare the characteristics of the litter from the two treatments prior to litterbag installation. Differences in overall decay constants as well as the proportion mass remaining, macronutrient concentrations, carbohydrate concentrations, and nutrient content remaining at the end of the study were assessed using a randomized block, split-plot design. The litter treatment location (burn or control) was the whole plot and the litter source (burn or control) was the subplot, while the stand was the blocking factor in the model. A mixed model analysis of variance (ANOVA) with stands (block) was considered as a random factor while treatment source and location and their interactions were fixed factors. When interactions were significant, mean separation was performed using least mean square separation using Tukey's Honestly Significant Difference (Tukey's HSD; Tukey 1977) adjustment. When information for each collection period was included in the analysis, a repeated measures with an autoregressive correlation structure was utilized for the analysis. Collection period and its interaction with treatment litter location and litter source were considered fixed factors. Again, least mean square separation using Tukey's HSD adjustment was used when interactions were significant. A repeated measurements randomized block design was used to assess difference in temperatures or soil moisture between treatment locations. All tests were performed at $\alpha=0.05$.

\section{Results}

Microclimate

Seasonal trends in litter temperature and soil moisture were similar in the burn and control treatment locations (Fig. 1a, b). Average daily air temperature $10 \mathrm{~cm}$ above the forest floor was slightly lower $\left(0.5\right.$ to $\left.0.6{ }^{\circ} \mathrm{C}\right)$ than that measured in the litter. Air temperature, litter temperature, and soil moisture content averaged $17.2^{\circ} \mathrm{C}$, $17.8{ }^{\circ} \mathrm{C}$, and $24.4 \%$, respectively, in the burn treatment, and $17.2{ }^{\circ} \mathrm{C}, 17.6{ }^{\circ} \mathrm{C}$, and $23.8 \%$, respectively, in the control treatment. Air temperature $(P=0.875)$, litter temperature $(P=0.173)$, and soil moisture content $(P=$ 0.153 ) did not significantly differ between the burn and control treatment locations. Treatment by collection period interactions (air temperature, $P=0.680$; litter temperature, $P=0.667$; and soil moisture content, $P=$ 0.795 ) were also not significant. Litter moisture content during the last six collection periods averaged $65.1 \%$ and $65.5 \%$ in the burn and control treatments, respectively. Treatment $(P=0.983)$ and treatment $\times$ collection date interaction terms $(P=0.871)$ were not significant. These results suggest that the microclimate experienced by litter was similar in the two treatments.

\section{Mass loss}

The litter on average lost $42.9 \%$ of its original ash-free mass by the end of the 472 days ( 15 months and 3 weeks) following bag deployment (Fig. 2). By the end of the study, mass loss did not significantly differ between locations $(P=0.532)$ or litter sources $(P=0.318)$. Average ash-free mass loss was $41.7 \%$ and $44.1 \%$ in the burn and control treatments, respectively, and $43.9 \%$ and $41.9 \%$ for the burn and control litter sources, respectively. Location by source interactions were not significant $(P=0.710)$.

The average overall decomposition decay constant $\left(k_{\mathrm{o}}\right)$ measured in this study was $0.44 \mathrm{yr}^{-1}$. Although the proportion of mass remaining at the end of the study was similar for the two sources of litter, decay constants significantly differed $(P=0.013)$ between litter sources, indicating significantly greater decomposition for foliar litter originating from the burn compared to the control treatment (Table 1). Litter decay constants did not significantly differ by treatment location $(P=0.096)$ and neither was the location by litter source interaction significant $(P=0.997)$.

Comparisons of $k$ constants calculated for each individual collection date indicated no significant difference between treatment locations $(P=0.084)$, but did indicate significant differences between litter sources $(P<0.001)$. The litter source by collection date interaction was also significant $(P<0.001)$. Rate constants were significantly greater for foliar litter originating from the burn (higher decomposition) than that originating from the control 

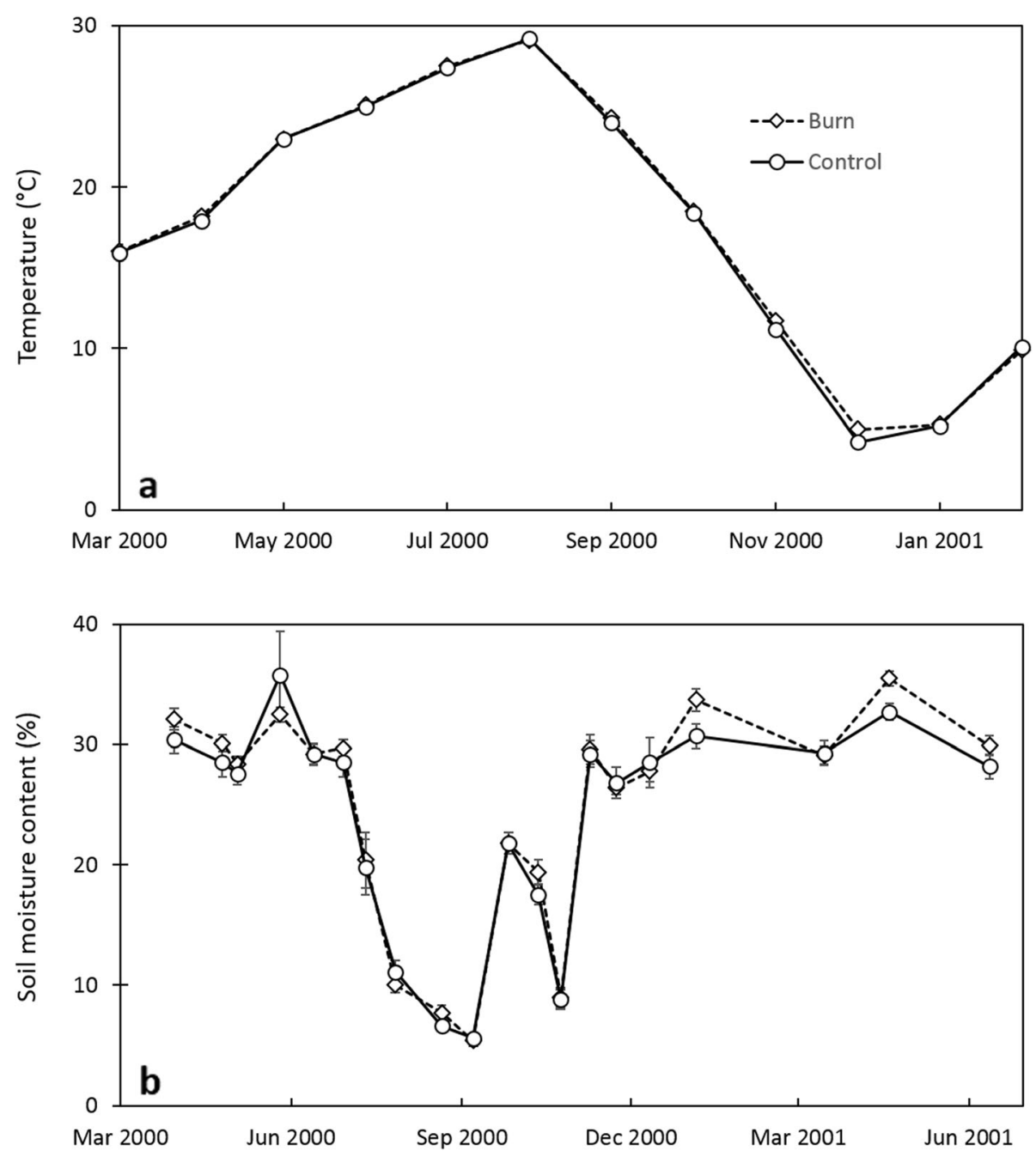

Fig. 1 Mean ( \pm 1 standard error) (a) litter temperature and (b) soil moisture content at $3 \mathrm{~cm}$ depth in plots with (Burn) and without (Control) prescribed fire in three uneven-age loblolly-shortleaf pine stands during a 472-day study (24 Feb 2000 to 10 Jun 2001) in southeastern Arkansas, USA

treatment during the first 30 days after litterbag deployment (Fig. 3). However, rate constants calculated for litter collected on the 26 Apr 2000 collection date (62 days after deployment) and thereafter did not significantly differ between litter sources. Average rate constants during the first 30 days after deployment were 0.74 and $0.15 \mathrm{yr}^{-1}$ for litter originating from the burn and control treatments, respectively.

\section{Carbon fractions and nutrients}

Lignin and cellulose ash-free concentrations prior to bag installation did not significantly differ $(P=0.531$ and $P=0.341$, respectively) between litter originating in the burn (472 and $217 \mathrm{~g} \mathrm{~kg}^{-1}$, respectively) and control (453 and $220 \mathrm{~g} \mathrm{~kg}^{-1}$, respectively) treatments. Differences in ash-free concentrations and the proportion of the initial amounts of cellulose and lignin remaining in litter following deployment did not significantly differ $(P=$ 0.151 to $P=0.804$ ) by litter source or location 15,251 , or 472 days following litterbag deployment. Concentrations of lignin tended to increase while concentrations of cellulose decreased during the approximately 16-month study period (Table 2). The proportion of the litter mass (42.9\%) and lignin (42.6\%) lost during the 472-day study period were similar (Table 2).

Although differences were small (13 to $22 \%$ ), concentrations of $\mathrm{P}, \mathrm{K}, \mathrm{Ca}$, and $\mathrm{Mg}$ prior to litter deployment were significantly higher for litter obtained from the burn than from the control treatment (Table 3). This corresponded to a lower loss on ignition in the burn compared to the control treatment. Differences in $\mathrm{N}$ and $\mathrm{C}$ between treatment sources were not significant (Table 3). Mean litter source C:N and C:P ratios were 112 and 2222, respectively, for the burn treatment, 


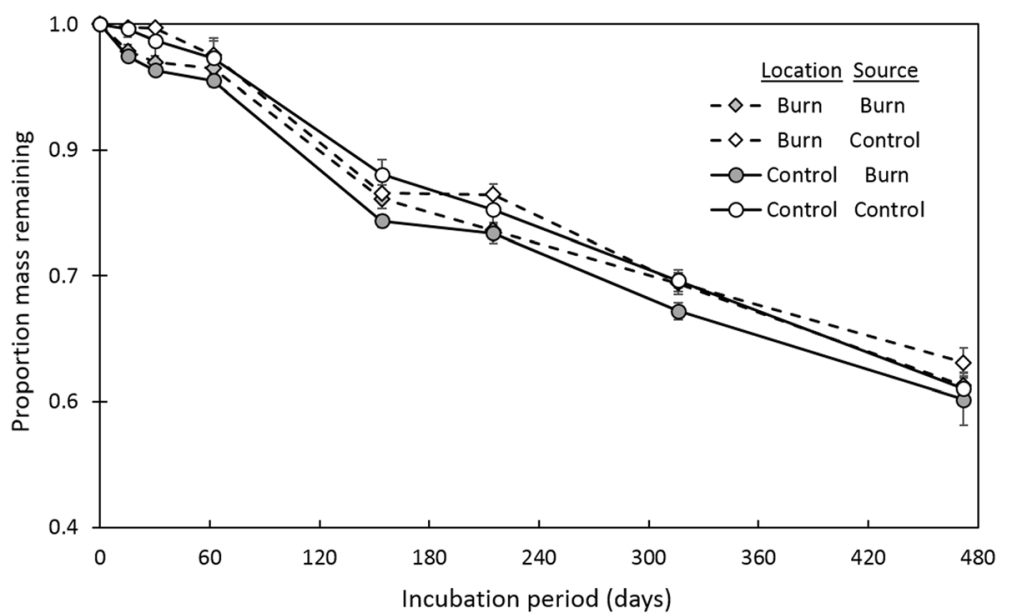

Fig. 2 Mean ( \pm 1 standard error) proportion of mass remaining for loblolly pine foliar litterfall by treatment location (Burn and Control) and source (Burn and Control) in three uneven-age loblolly-shortleaf pine stands during a 472-day study (24 Feb 2000 to 10 Jun 2001) in southeastern Arkansas, USA

compared to 113 and 1819, respectively, for the control treatment. Differences between treatments were not significant $(P=0.908)$ for $\mathrm{C}: \mathrm{N}$ ratios but were significant $(P=0.009)$ for C:P ratios. Lignin:N ratios computed from the mean lignin and $\mathrm{N}$ concentrations were 101 for each litter source.

Carbon loss from the litter was similar to the loss in litter mass and, by the end of the study, $42.1 \%$ of the carbon was lost from the litter (Table 4). Nitrogen and calcium were generally retained in the litter and, by the end of the study, these two macronutrients were at levels similar to that at the initiation of the study (Fig. 4b and e). Phosphorus increased rapidly following litterbag deployment (Fig. 4c) and, by the end of the study, P levels were on average $26 \%$ higher than that at the time of deployment. Approximately $3.0 \mathrm{mg}$ of $\mathrm{P}$ was immobilized in the litter during the first 15-day incubation period, and $\mathrm{P}$ content was typically greater during the first 30 days of incubation than during the remainder of the study (Fig. 4b). Concentrations of $\mathrm{P}$ in the litter were low and variations in the proportion of $\mathrm{P}$ remaining for any collection date and treatment combination were frequently high. Losses of $\mathrm{K}$ and $\mathrm{Mg}$ were substantial

Table 1 Mean (standard error) overall decomposition decay constants $\left(k_{0}\right)$ for control and burn treatment locations and litter source in three loblolly-shortleaf pine stands during a 472-day study (24 Feb 2000 to 10 Jun 2001) in southeastern Arkansas, USA

\begin{tabular}{lll}
\hline & Source & \\
\cline { 2 - 3 } Location & Control & Burn \\
\hline Control & $0.43(0.02) a^{1}$ & $0.48(0.03) b$ \\
Burn & $0.41(0.02) a$ & $0.46(0.01) b$ \\
\hline
\end{tabular}

${ }^{1}$ Means with the same letter do not significantly differ, $a=0.05$ following the first 30 days of incubation (Fig. 4d and f). The amount of $\mathrm{K}$ and $\mathrm{Mg}$ within the litter at the end of the study was significantly lower than that following the first 30-day incubation period. Potassium, like P, was immobilized by the litter during the first 15 days of the study. Total amounts of $\mathrm{K}$ immobilized during this period were 4.3 and $8.4 \mathrm{mg}$ for the foliar litter initially collected from the burn and control treatments, respectively.

For the majority of the macronutrients studied, the proportion of the initial nutrient content that remained at the end of the study did not differ by treatment location or foliar litter source (Table 4). The proportion of $\mathrm{K}$ content remaining at this time was higher (Table 4; $P=0.010)$ for the litter originating from the control compared to from the burn treatment. A total of $60.4 \%$ of the $\mathrm{K}$ was lost from the litter originating in the burn treatment, but only $55.3 \%$ from litter originating in the control treatment. Given the higher concentrations of $\mathrm{K}$ for litter originating from the burn treatment (Table 3), the average losses of $\mathrm{K}$ for this litter $(15.5 \mathrm{mg})$ were much greater than that for control litter $(11.4 \mathrm{mg})$. The only nutrient that showed a significant treatment interaction was $\mathrm{P}(P<0.001)$. The proportion of $\mathrm{P}$ remaining in the control litter was significantly higher than that in burn litter when located in the control treatment (Table 4).

At the end of the study, ash-free concentrations for most nutrients, with the exception of $\mathrm{K}$ and $\mathrm{Mg}$ (Table 4), were greater than that of the litter prior to deployment (Table 3). Differences in concentrations by location were not significant for any macronutrient concentration. Only ash-free concentrations of Ca differed by litter source $(P=0.016)$ at the end of the study. 


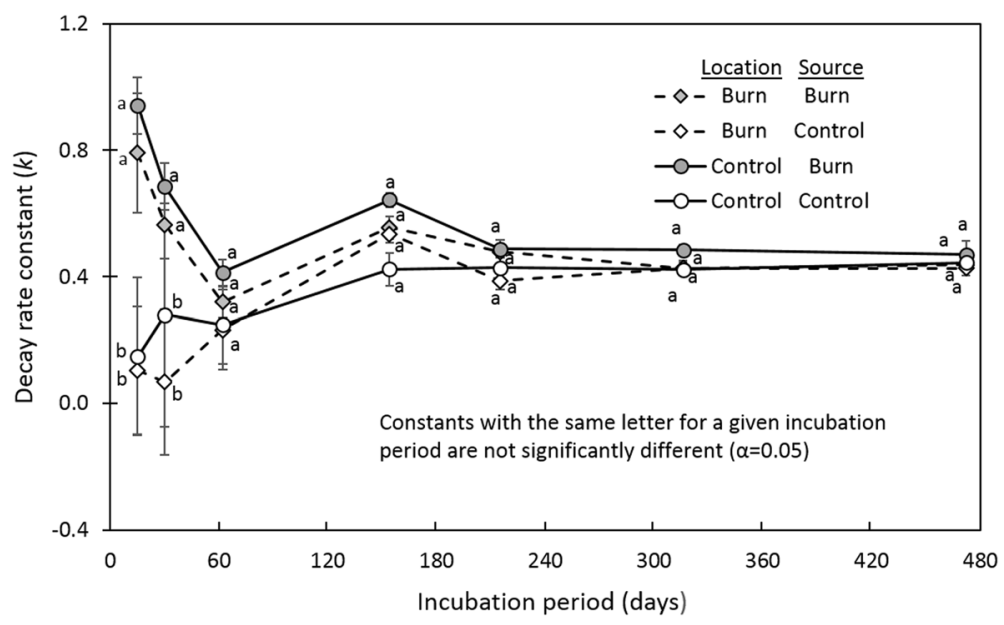

Fig. 3 Mean ( \pm 1 standard error) decay rate constant $k$ by treatment location (Burn and Control) and source (Burn and Control) in three unevenage loblolly-shortleaf pine stands during a 472-day study (24 Feb 2000 to 10 Jun 2001) in southeastern Arkansas, USA

As was found prior to litterbag deployment, Ca concentrations were higher for litter originating in the burn compared to litter originating in the control treatment.

\section{Discussion}

\section{Decomposition}

Overall decay constants determined by our study $(0.41$ to 0.48 ) were at the upper end of those reported for loblolly pine foliar litter in the southern United States (Table 5) and were most similar to those reported for unthinned, mid-rotation (12- to 14-year-old) plantations (Piatek and Allen 2001; Gurlevik et al. 2003) and a fertilized seven-year-old plantation (Sanchez 2001). While the incubation period in our study was only approximately 16 months, decomposition decay constants calculated from litter installed in the control treatment were similar to those from the studies in Table 5 that utilized incubation periods of 26 to 36 months.

Although several studies in a variety of forest ecosystems have found altered litter decomposition rates up to several years following low intensity fires (Raison et al. 1986; Schoch and Binkley 1986; Monleon and Cromack 1996; Köster et al. 2015), foliar litter deployed in the burn and control treatments in our study had similar mass loss and overall decay constants. Decomposition rates are strongly dependent on environmental conditions (Swift et al. 1979; Berg and McClaugherty 2014) and fires that remove vegetation can increase insolation, which can increase temperatures and reduce litter moisture (Raison et al. 1986; Hernández and Hobbie 2008). Decomposition rates can be reduced as a result of the reduction in litter moisture that occurs with the removal of vegetation or forest floor by fire (Raison et al. 1986; Köster et al. 2015) as well as other cultural treatments (Gurlevik et al. 2003).

A previous study in our stands (Liechty and Hooper 2016) reported that, at the time of litterbag deployment (Feb 2000), there was $37.8 \%$ less forest floor mass and, by the end of the 2001 growing season, 85.1\% less sapling biomass in the burn compared to the control treatment. These changes in forest floor and vegetation appeared to have minimal impact on the microclimate (Fig. 1a and b) and thus presumably decomposition. The lack of microclimate differences between the two treatments was likely due to the rapid recovery of the $\mathrm{O}_{i}$ horizon and understory vegetation following the Oct 1998 fire (Liechty and Hooper 2016) and the maintenance of similar overstory canopy cover by the selection

Table 2 Mean (standard error) proportion of total mass, lignin, and cellulose remaining as well as ash-free lignin and cellulose concentrations measured following three incubation periods in three loblolly-shortleaf pine stands during a 472-day study (24 Feb 2000 to 10 Jun 2001 ) in southeastern Arkansas, USA

\begin{tabular}{|c|c|c|c|c|c|}
\hline \multirow[b]{2}{*}{ Incubation period (days) } & \multicolumn{3}{|c|}{ Mean proportion (\%) } & \multicolumn{2}{|c|}{ Mean concentration $\left(\mathrm{g} \mathrm{kg}^{-1}\right)$} \\
\hline & Total mass & Lignin & Cellulose & Lignin & Cellulose \\
\hline 15 & $97.9(0.57) a^{1}$ & $97.7(0.66) \mathrm{a}$ & $95.3(0.65) a$ & $441(1.1) c$ & 207 (1.3)a \\
\hline 215 & $75.9(0.62) \mathrm{b}$ & $82.3(0.96) b$ & $71.4(0.77) \mathrm{b}$ & $486(2.0) \mathrm{a}$ & 204 (1.0)a \\
\hline 472 & $58.4(1.57) \mathrm{c}$ & $57.4(1.47) \mathrm{C}$ & $50.8(1.39) \mathrm{C}$ & $457(3.4) b$ & $195(3.4) b$ \\
\hline
\end{tabular}

${ }^{1}$ Means with the same letter for a specific litter parameter do not significantly differ, $a=0.05$ 
Table 3 Mean organic matter loss on ignition ( $\mathrm{LOl} \mathrm{g} \mathrm{kg}^{-1}$ ) and ash-free concentrations of six nutrients (carbon, C; nitrogen, N; phosphorus, P; potassium, K; calcium, Ca; and magnesium, Mg) for pine foliar litter collected from three loblolly-shortleaf pine stands prior to a 472-day study (24 Feb 2000 to 10 Jun 2001) in southeastern Arkansas, USA

\begin{tabular}{lrrlllll}
\hline Source & $\begin{array}{l}\text { Organic matter } \\
\text { LOl }\left(\mathrm{g} \mathrm{kg}^{-1}\right)\end{array}$ & \multicolumn{6}{c}{ Nutrient concentration $\left(\mathrm{g} \mathrm{kg}^{-1}\right)$} \\
\cline { 3 - 8 } & \multicolumn{1}{c}{$\mathrm{C}$} & $\mathrm{N}$ & $\mathrm{P}$ & $\mathrm{K}$ & $\mathrm{Ca}$ & $\mathrm{Mg}$ \\
\hline Burn & 953 & 502 & 4.47 & 0.28 & 1.39 & 3.85 & 0.96 \\
Control & 958 & 504 & 4.49 & 0.23 & 1.15 & 3.42 & 0.81 \\
P-value & 0.001 & 0.919 & 0.099 & 0.039 & 0.025 & 0.009 & 0.001 \\
\hline
\end{tabular}

harvests. Additionally, losses of vegetation from dormantseason fires in our stands may be relatively low. Henry (2006) found that a prescribed fire applied on 4 Jan 2002 in the burn treatment only consumed $30 \%$ of the understory vegetation. The relative low levels of understory loss likely reflect low fire intensities during the dormant season as result of high moisture contents of the poorly drained Bude soils. Prescribed fires at more xeric sites or during drier times of the year may result in a greater reduction of forest floor or vegetation, which could have a greater effect on microclimate and thus potentially decomposition.

Prescribed fire in the burn treatment also resulted in changes in forest floor composition (Liechty and Hooper 2016). At the time of litterbag installation, the ratio of pine to broadleaf woody foliage in the $\mathrm{O}_{\mathrm{i}}$ horizon of the burn treatment was 6.9 compared to 1.8 in the control treatment. Gartner and Cardon (2004) reported that, in

Table 4 Proportion of carbon (C), nitrogen (N), phosphorus (P), potassium (K), calcium (Ca), and magnesium (Mg) content remaining, as well as ash-free nutrient concentrations $\left(\mathrm{g} \mathrm{kg}^{-1}\right)$ for each litter location and source combination in three loblolly-shortleaf pine stands at the end of a 472-day study (24 Feb 2000 to 10 Jun 2001) in southeastern Arkansas, USA

\begin{tabular}{llllllll}
\hline & & \multicolumn{7}{l}{ Proportion content remaining } \\
\cline { 3 - 8 } Location & Source & $\mathrm{C}$ & $\mathrm{N}$ & $\mathrm{P}$ & $\mathrm{K}$ & $\mathrm{Ca}$ & $\mathrm{Mg}$ \\
\hline Burn & Burn & $0.58 \mathrm{a}^{1}$ & $1.08 \mathrm{a}$ & $1.23 \mathrm{ab}$ & $0.41 \mathrm{~b}$ & $1.00 \mathrm{a}$ & $0.63 \mathrm{a}$ \\
Burn & Control & $0.60 \mathrm{a}$ & $1.04 \mathrm{a}$ & $1.24 \mathrm{ab}$ & $0.46 \mathrm{a}$ & $0.97 \mathrm{a}$ & $0.62 \mathrm{a}$ \\
Control & Burn & $0.56 \mathrm{a}$ & $1.04 \mathrm{a}$ & $1.15 \mathrm{~b}$ & $0.38 \mathrm{~b}$ & $0.90 \mathrm{a}$ & $0.77 \mathrm{a}$ \\
Control & Control & $0.57 \mathrm{a}$ & $1.10 \mathrm{a}$ & $1.41 \mathrm{a}$ & $0.47 \mathrm{a}$ & $0.94 \mathrm{a}$ & $0.90 \mathrm{a}$
\end{tabular}

Ash-free nutrient concentration $\left(\mathrm{g} \mathrm{kg}^{-1}\right)$

$\begin{array}{llllllll}\text { Location } & \text { Source } & C & N & P & \text { K } & \text { Ca } & \text { Mg } \\ \text { Burn } & \text { Burn } & 515 a & 8.49 a & 0.60 \mathrm{a} & 1.00 \mathrm{a} & 6.75 \mathrm{a} & 1.05 \mathrm{a} \\ \text { Burn } & \text { Control } & 508 \mathrm{a} & 7.92 \mathrm{a} & 0.50 \mathrm{a} & 0.91 \mathrm{a} & 5.67 \mathrm{~b} & 0.86 \mathrm{a} \\ \text { Control } & \text { Burn } & 508 \mathrm{a} & 8.49 \mathrm{a} & 0.58 \mathrm{a} & 0.95 \mathrm{a} & 6.33 \mathrm{a} & 1.32 \mathrm{a} \\ \text { Control } & \text { Control } & 510 \mathrm{a} & 8.89 \mathrm{a} & 0.60 \mathrm{a} & 0.99 \mathrm{a} & 5.80 \mathrm{~b} & 1.34 \mathrm{a}\end{array}$

${ }^{1}$ Means with the same letter for a specific element and parameter do not significantly differ, $a=0.05$
$67 \%$ of the trials they reviewed, decomposition of mixed species foliage was significantly different than that predicted by decomposition for each individual species separately. Piatek and Allen (2001) reported more rapid loblolly pine litter decomposition when mixed at a ratio of 1:5 with hardwood foliage. These changes in forest floor composition within the areas where our litterbags were installed did not appear to alter the decomposition of the loblolly pine foliar litter in the litterbags.

Unlike the decomposition rates associated with treatment locations, decomposition dynamics differed between litter sources. Decomposition rates during the first 30 days were significantly greater for the foliar litter originating from the burn than the control treatment (Fig. 3). During the initial stages of decomposition, foliar leaching is an important component of mass loss (MacLean and Wein 1978; Tietema and Wessel 1994; Trofymow et al. 2002; Jiang et al. 2016). Higher rates of mass loss for the burntreatment litter shortly after bag installation may reflect accelerated rates of leaching of carbohydrates or nutrients. The greater losses of $\mathrm{K}$ from the litter originating from the burn treatment are consistent with a potential increase in leaching as a result of prescribed fire.

Accelerated leaching of foliage can be a result of physical damage (Tukey 1970). Increased foliar or litter leaching has been attributed to injury from such factors as atmospheric pollution (Schier and Jensen 1992) and freeze-thaw cycles (Taylor and Parkinson 1988). Potentially, the higher rates of mass loss of the burn-treatment foliage during the first 30 days of litter deployment could be related to foliar damage from the prescribed fire. Foliar litter collected for our study was present on the trees during the Oct 1998 prescribed fire. Heat from the fire may have damaged foliage on midstory trees and perhaps the lower branches of dominant or codominant trees, thereby accelerating leaching of the senesced foliage. However, nutrient concentrations of the litter collected from the burn treatment was similar to or greater than that of litter collected from the control treatment (Table 4) and no visual signs of injury were noted for the burn treatment litter at the time of collection. Thus, prescribed fire appeared to, at most, have a minor impact on foliar physical damage and leaching losses.

Any alteration of the foliage by the prescribed fire appeared to have an ephemeral influence on decomposition and, by the end of the study, total mass loss was similar between foliar litter sources. Changes in decomposition rates with long-term use of prescribed fire have frequently been attributed to changes in $\mathrm{N}$ and thus litter quality (Hernández and Hobbie 2008; Brennan et al. 2009; Ficken and Wright 2017). Litter quality characteristics such as $\mathrm{C}: \mathrm{N}$ and lignin: $\mathrm{N}$ did 

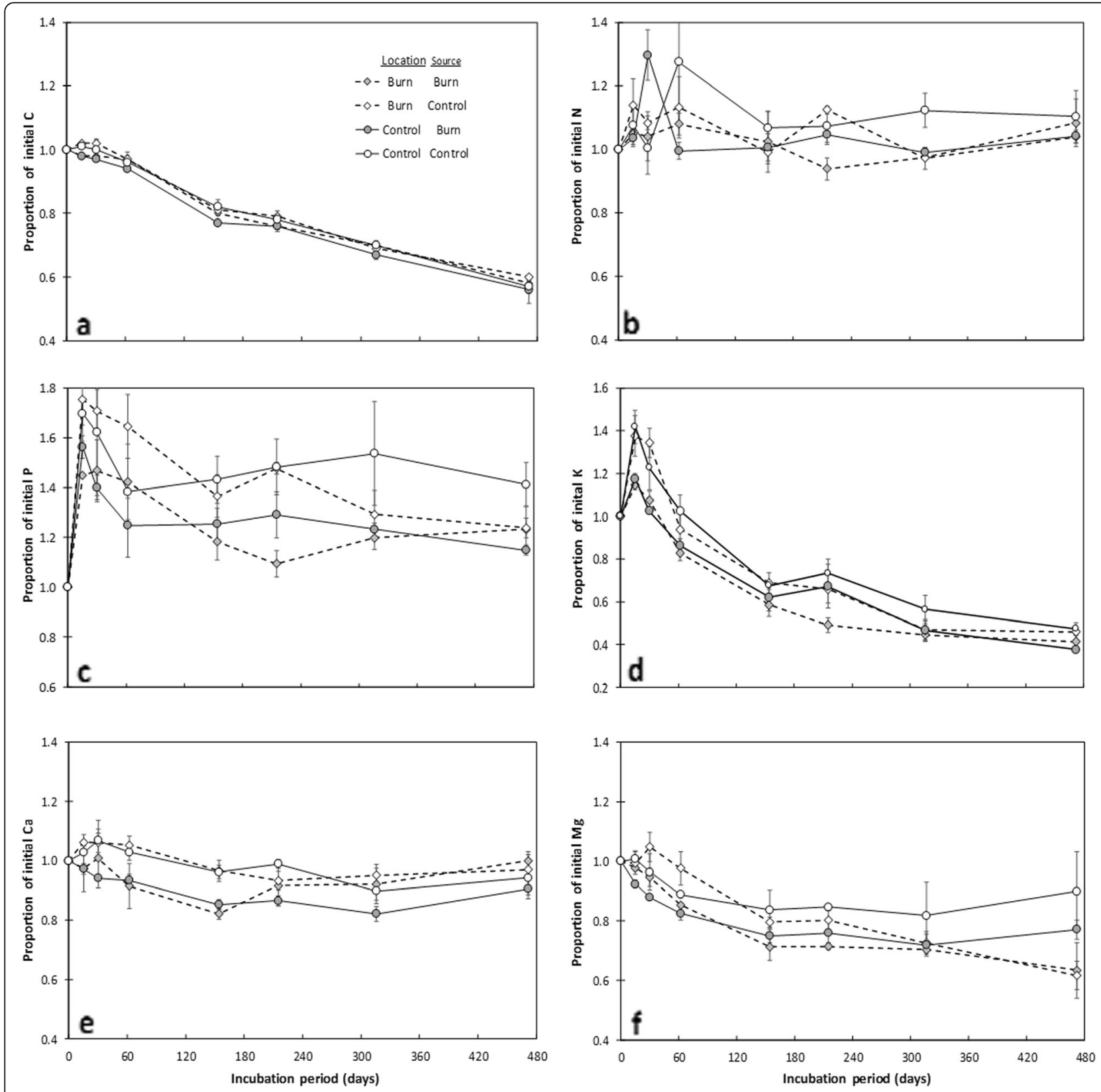

Fig. 4 Mean $( \pm 1$ standard error) proportion of initial (a) carbon $(C),(\mathbf{b})$ nitrogen $(N),(\mathbf{c})$ phosphorus $(P),(\mathbf{d})$ potassium $(K),(\mathbf{e})$ calcium $(C a)$, and (f) magnesium (Mg) content by treatment location (Burn and Control) and source (Burn and Control) in three uneven-age loblolly-shortleaf pine stands during a 472-day study (24 Feb 2000 to 10 Jun 2001) in southeastern Arkansas, USA

Table 5 Decay rate constants previously published for loblolly pine foliar litterfall in stands ranging from 9 to 15 years of age at the time of litterbag installation

\begin{tabular}{lllll}
\hline Study & No treatment & Fertilization & Irrigation & Vegetation control \\
\hline Sanchez 2001 & $0.33,0.34$ & $0.43,0.41$ & $0.35,0.35$ & \\
Piatek and Allen 2001 $^{2}$ & $0.41,0.43$ & & & \\
Gurlevik et al. 2003 & 0.39 & 0.40 & 0.27
\end{tabular}

${ }^{1}$ Rate constants calculated from high- and low-quality pine foliage litter. Treatments were applied annually in the area of the decomposition study

${ }^{2}$ Rate constants for foliage collected from two different 15-year-old stands

${ }^{3}$ Treatments were applied once just prior to initiation of the decomposition study not significantly differ between litter sources in our study. Therefore, it is not surprising that total mass loss was similar for the foliar litter originating from the burn and control treatments. Low levels of $\mathrm{P}$ in foliar litter are thought to limit decomposition during the early stages of decomposition when lignin content has a minimal impact on mass loss (Enríquez et al. 1993; Berg 2000). Although the P concentration and $\mathrm{C}: \mathrm{P}$ ratio of the litter originating in the burn treatment significantly differed from that originating in the 
control treatment, mass loss at the end of the study and decomposition rates following the first 30 days of incubation were similar for these two sources of foliar litter. The results of our study indicated that the use of prescribed fire in these frequently harvested loblolly-short leaf pine stands should have little or no effect on litter quality and long-term litter decomposition rates.

\section{Nutrient dynamics}

Although the higher concentrations of macronutrients in the litterfall originating from the burn treatment (Table 4) could potentially be a result of an increase in nutrient availability with prescribed fire, Liechty and Hooper (2016) found no indication of increases in nutrient availability in the burn treatment within the three stands. Live foliage and soil surface nutrient concentrations collected just prior to the initiation of the litter decomposition study were not found to significantly differ between the control and burn treatments (Liechty and Hooper 2016). Differences in the initial nutrient concentrations from the two litter sources may reflect differences in the type of foliage collected in the two treatments. The litterfall collected in our study included loblolly pine foliage from not only the upper portion of the canopy-foliage that was used to determine nutrient concentrations of live foliage-but also foliage from the lower crowns of overstory trees, midstory trees, and saplings. Litterfall in the burn treatment likely included a much lower amount of foliage from saplings and the lower strata of the canopy due to the lack of loblolly pine seedling recruitment into sapling-size trees (Cain and Shelton 2002; Liechty and Hooper 2016) and scorching of foliage in the lower portion of the canopy. Given the lack of differences in nutrient concentrations reported by Liechty and Hooper (2016), as well as the potential variability in the foliage contributing to the litterfall in the two treatments, it is not likely the differences in $\mathrm{P}, \mathrm{K}, \mathrm{Ca}$, or $\mathrm{Mg}$ concentrations were a result of fire-mediated differences in nutrient availability. In addition, several studies have documented changes in $\mathrm{N}$ availability and thus litter $\mathrm{N}$ concentrations with frequent, long-term use of prescribed fires (Hernández and Hobbie 2008; Williams et al. 2012; Ficken and Wright 2017). Nitrogen concentrations of the foliar litter from the two treatments in our study were very similar and did not suggest any changes in $\mathrm{N}$ availability with prescribed fire. Liechty and Hooper (2016) hypothesized that inclusion of harvesting with the application of prescribed fire may limit the changes in nutrient availability frequently reported with the long-term use of prescribed fire.
During the first 30 days following litterbag installation, $\mathrm{N}, \mathrm{P}$, and $\mathrm{K}$ concentrations rapidly increased in the litter (Fig. 4b, c, and d). Increases in one or more of these elements have been attributed to establishment of microbial and fungal biomass (Gosz et al. 1973; Berg and Soderstrom 1979; Tian et al. 2003), atmospheric deposition (Gurlevik et al. 2003), or transfer of nutrients from nutrient-rich substrates (Gurlevik et al. 2003). Nitrogen and P continued to be immobilized in the litter following the initial 30-day incubation period, but $\mathrm{P}$ was immobilized more strongly than N (Fig. 4b and c). These results indicated that decomposition was limited by both $\mathrm{N}$ and $\mathrm{P}$ in these stands during the study. The long period of $\mathrm{N}$ and $\mathrm{P}$ immobilization, while potentially unusual, has been reported by other studies that monitored nutrient dynamics in decomposing loblolly pine litter. Piatek and Allen (2001) reported $\mathrm{N}$ immobilization during a 14-month period and $\mathrm{P}$ immobilization during a 26-month incubation period. Gurlevik et al. (2003) reported $\mathrm{N}$ immobilization for incubation periods of up to 32 months in a loblolly stand that received a competition control treatment. Piatek and Allen (2001) concluded that the forest floors in the loblolly pine stands they studied were $\mathrm{N}$ and $\mathrm{P}$ sinks rather than sources of available $\mathrm{N}$ and P. Our initial results appear to indicate that the litter in our study is also an $\mathrm{N}$ and $\mathrm{P}$ sink.

Immobilization of $\mathrm{N}$ was similar for each litter source and location, but more $\mathrm{P}$ was immobilized and, following the initial immobilization of $\mathrm{P}$, less was released by foliar litter that originated in the control than in the burn treatment (Fig. 4c). Polglase et al. (1992) found that the amount of $\mathrm{P}$ released from decomposing pine foliage was strongly correlated with the initial P content of the litter. Gurlevik et al. (2003) also suggested that the length of time $\mathrm{P}$ was immobilized in decomposing litter was negatively correlated with the initial concentration of $\mathrm{P}$ in litter. In our study, $\mathrm{P}$ concentration prior to incubation (Table 3) was $18 \%$ lower in litter originating in the control compared to litter originating in the burn treatment. The lower P concentration associated with the control litter may have increased the amount of $\mathrm{P}$ immobilized by this litter source or may affect the length of time before $P$ is released from the decomposing litter. By the end of the study, $\mathrm{N}$ and $\mathrm{P}$ content was still at or above levels in the foliar litter prior to litterbag deployment for all treatment combinations (Fig. $4 \mathrm{~b}$ and c).

While $\mathrm{N}$ and $\mathrm{P}$ were immobilized by the decomposing litter, $\mathrm{K}$ was released and, at the end of the first 62-day incubation period, the amount of $\mathrm{K}$ in the litter was lower than that at the beginning of the study. Potassium is a mobile nutrient and frequently found to be rapidly 
lost from decomposing pine litter (Piatek and Allen 2001; Gurlevik et al. 2003). Losses of $\mathrm{K}$ in our study were greater for litter originating from the burn than the control treatment. The increased loss of $\mathrm{K}$ from this source of litter was consistent with the more rapid mass loss associated with this litter source during the initial 30 -day incubation period. Loss of $\mathrm{K}$, at least initially during the decomposition process, is attributed to leaching of this cation. Tietema and Wessel (1994) indicate that large portions of $\mathrm{K}$ occur in the form of soluble salts within cells, which can be leached when cell membranes are damaged. Potentially, the 1998 prescribed fire damaged the cell membranes of a portion of the foliage and is responsible for the accelerated $\mathrm{K}$ loss from the litter that originated in the burn treatment. However, there was no evidence of any damage when the litter was collected in this treatment. The higher rates of $\mathrm{K}$ loss associated with litter originating in the burn treatment may also in part reflect the elevated concentrations of $\mathrm{K}$ in this foliage prior to litterbag deployment (Table 4). Although initial concentrations of $\mathrm{Ca}$ and $\mathrm{Mg}$ were also greater in the burn than the control treatment, the magnitude of losses of $\mathrm{Ca}$ and $\mathrm{Mg}$ were similar in the two treatments.

Although changes in nutrient dynamics occurred with prescribed fire in these managed stands, the changes were minimal. Land managers are often concerned that excessive harvesting and application of prescribed fires can reduce onsite nutrient pools or nutrient availability as a result of biomass removal (Hume et al. 2017), increased nutrient leaching (Jerabkova et al. 2011; Binkley and Fisher 2013), and, in the case of prescribed fire, gaseous and particulate fluxes to the atmosphere (Carter and Foster 2004). Prescribed fire in our study did not appear to appreciably alter rates of nutrient release from decomposing litter and thus exacerbate any other losses of nutrients or reductions in nutrient availability associated with harvesting or prescribed fire. Typical changes in nutrient pools or availability as a result of biomass removal, leaching, and release to the atmosphere likely far overshadow any fire-mediated changes in nutrients associated with decomposition in loblolly-shortleaf pine stands managed with periodic, partial harvests.

\section{Conclusions}

We found minimal changes in litter mass loss or nutrient dynamics related to prescribed fire in these loblollyshortleaf pine stands. Changes in forest floor amounts and vegetation associated with eight dormant-season prescribed fires had little impact on litter microclimate, which likely contributed to the unaltered decomposition rates of loblolly pine foliar litter in this study. Rapid regrowth of understory following prescribed fire as a result of periodic harvesting of overstory trees may have contributed to the similarity in microclimate, and thus decomposition. Concentrations of $\mathrm{P}, \mathrm{K}, \mathrm{Ca}$, and $\mathrm{Mg}$ appeared to be slightly elevated in loblolly pine litter with prescribed fire. However, litter quality indices such as litter $\mathrm{N}$ concentration, $\mathrm{C}: \mathrm{N}$, and lignin: $\mathrm{N}$ were not altered by the use of prescribed fire. These results provide evidence that forest management or restoration activities that include prescribed fire in periodically harvested pine stands within the upper Gulf Coastal Plain will likely not significantly alter decomposition or nutrient release from decomposing litter.

\section{Acknowledgements}

The authors would also like to thank M.G. Shelton and M.D. Caine for the initial development of the overall research design and implementation of the prescribed fire and harvesting treatments.

\section{Authors' contributions}

HOL developed the study, performed the analysis, and wrote the manuscript. MR collected data and performed laboratory analyses. All authors read and approved the manuscript.

\section{Funding}

USDA Forest Service Southern Research Station and Arkansas Forest Research Center financially supported this project.

\section{Availability of data and materials}

The datasets generated or analyzed during the current study are available from the corresponding author on reasonable request.

Ethics approval and consent to participate

Not applicable.

\section{Consent for publication}

Not applicable.

\section{Competing interests}

The authors declare that they have no competing interests.

\section{Author details}

${ }^{1}$ Arkansas Forest Resource Center, 110 University Court, Monticello, AR 71656, USA. ${ }^{2}$ Division of Math and Science, Missouri Valley College, 500 East College, Marshall, MO 65340, USA.

Received: 24 April 2019 Accepted: 13 December 2019

Published online: 31 January 2020

\section{References}

Alder, P.R., and G.E. Wilcox. 1985. Rapid perchloric acid digest methods for analysis of major elements in plant tissue. Communications in Soil Science and Plant Analysis 16: 1153-1163 https://doi.org/10.1080/00103628509367673.

Ball, D.F. 1964. Loss-on-ignition as an estimate of organic matter and organic carbon in non-calcareous soils. Journal of Soil Science 15: 84-92 https://doi. org/10.1111/j.1365-2389.1964.tb00247.x.

Bell, R., and D. Binkley. 1989. Soil nitrogen mineralization and immobilization in response to periodic prescribed fire in a loblolly pine plantation. Canadian Journal of Forest Research 19: 816-820 https://doi.org/10.1139/×89-125.

Berg, B. 2000. Litter decomposition and organic matter turnover in northern forest soils. Forest Ecology and Management 133: 13-22 https://doi.org/10. 1016/S0378-1127(99)00294-7.

Berg, B., and C. McClaugherty. 2014. Plant litter: decomposition, humus formation, carbon sequestration. Berlin: Springer-Heidelberg.

Berg, B., and B. Soderstrom. 1979. Fungal biomass and nitrogen in decomposing Scots pine needle litter. Soil Biology and Biochemistry 11: 339-341 https://doi. org/10.1016/0038-0717(79)90045-2.

Binkley, D., and R.F. Fisher. 2013. Ecology and management of forest soils. 4th edition. Hoboken: Wiley. 
Binkley, D., D. Richter, M.B. David, and D. Caldwell. 1992. Soil chemistry in a loblolly/longleaf pine forest with interval burning. Ecological Applications 2: 157-164 https://doi.org/10.2307/1941772.

Brennan, K.E., F.J. Christie, and A. York. 2009. Global climate change and litter decomposition: more frequent fire slows decomposition and increases the functional importance of invertebrates. Global Change Biology 15: 2958-2971 https://doi.org/10.1111/j.1365-2486.2009.02011.x.

Cain, M.D. 1993. A 10-year evaluation of prescribed winter burns in uneven-aged stands of Pinus taeda $L$. and $P$. enchinata Mill.: woody understory vegetation response. International Journal of Wildland Fire 3: 13-20 https://doi.org/10. 1071/WF9930013

Cain, M.D., and M.G. Shelton. 2002. Does prescribed burning have a place in regenerating uneven-aged loblolly-shortleaf pine stands? Southern Journal of Applied Forestry 26: 117-123 https://doi.org/10.1093/sjaf/26.3.117.

Cain, M.D., T.B. Wigley, and D.J. Reed. 1998. Prescribed fire effects on structure in uneven-aged stands of loblolly and shortleaf pines. Wildlife Society Bulletin 26: 209-218.

Carter, M.C., and C.D. Foster. 2004. Prescribed burning and productivity in Southern pine forests: a review. Forest Ecology and Management 191: 93-109 https://doi.org/10.1016/j.foreco.2003.11.006.

Davis, M.W. 1998. A rapid modified method for compositional carbohydrate analysis of lignocellulosics by high $\mathrm{pH}$ anion-exchange chromatography with pulsed amperometric detection (HPAEC/PAD). Journal of Wood Chemistry and Technology 18: 235-252 https://doi.org/10.1080/02773819809349579.

Enríquez, S., C.M. Duarte, and K. Sand-Jensen. 1993. Patterns in decomposition rates among photosynthetic organisms: the importance of detritus C:N:P content. Oecologia 94: 457-471 https://doi.org/10.1007/BF00566960.

Ficken, C.D., and J.P. Wright. 2017. Effects of fire frequency on litter decomposition as mediated by changes in litter chemistry and soil environmental conditions. PLOS ONE 12 (10): e0186292 https://doi.org/10. 1371/journal.pone.0186292.

Gartner, T.B., and Z.G. Cardon. 2004. Decomposition dynamics in mixed-species leaf litter. Oikos 104: 230-246 https://doi.org/10.1111/j.0030-1299.2004.12738.x.

Gosz, J.R., G.E. Lickens, and F.H. Borman. 1973. Nutrient release from decomposing leaf and branch litter in the Hubbard Brook Forest, New Hampshire. Ecological Monographs 43: 173-191 https://doi.org/10.2307/ 1942193.

Guldin, J.M. 2007. Restoration and management of shortleaf pine in pure and mixed stands - science, empirical observation, and the wishful application of generalities. In: Shortleaf pine restoration and ecology in the Ozarks: proceedings of a symposium, USDA Forest Service General Technical Report NRS-P-15, ed. J.M. Kabrick, D.C. Dey, and D. Gwaze, 47-58. Newton Square: USDA Forest Service, Northern Research Station.

Gurlevik, N., D.L. Kelting, and H.L. Allen. 2003. The effects of vegetation control and fertilization on net nutrient release from decomposing loblolly pine needles. Canadian Journal of Forest Research 33: 2491-2502 https://doi.org/ 10.1139/x03-182

Haines, T.K., R.L. Busby, and D.A. Cleaves. 2001. Prescribed burning in the South: trends, purpose, and barriers. Southern Journal of Applied Forestry 25: 149-153 https://doi.org/10.1093/sjaf/25.4.149.

Henry, J.J. 2006. Nutrient and biomass changes from prescribed burning on an uneven-aged loblolly-shortleaf pine stand in Southeastern Arkansas. Thesis. Monticello: University of Arkansas.

Hernández, D.L., and S.E. Hobbie. 2008. Decomposition and nitrogen dynamics. Oecologia 158: 535-543 https://doi.org/10.1007/s00442-008-1162-3.

Hume, A.M., H.Y.H. Chen, and A.R. Taylor. 2017. Intensive forest harvesting increases susceptibility of Northern forest soils to carbon, nitrogen, and phosphorus loss. Journal of Applied Ecology 55: 246-255 https://doi.org/10. 1111/1365-2664.12942.

Jerabkova, L., C.E. Prescott, B.D. Titus, G.D. Hope, and M.B. Walters. 2011. A metaanalysis of the effects of clear cut and variable-retention harvesting on soil nitrogen fluxes in boreal and temperate forests. Canadian Journal of Forest Research 41: 1852-1870 https://doi.org/10.1139/x11-087

Jiang, L., K. Yue, Y. Yulian, and Q. Wu. 2016. Leaching and freeze-thaw events contribute to litter decomposition-a review. Sains Malaysian 45: 1041-1047.

Karberg, N.J., N.A. Scott, and C.P. Giardina. 2008. Methods for estimating litter decomposition. In: Field measurements for forest carbon monitoring: a landscape-scale approach, ed. C.M. Hoover, 103-111. Dordrecht: Springer https://doi.org/10.1007/978-1-4020-8506-2_8.

King, J.S, H.L. Allen, P. Dougherty, and B.R. Strain. 1997. Decomposition of roots in loblolly pine: effects of nutrient and water availability and root size class on mass loss and nutrient dynamics. Plant and Soil 195: 171-184 https://doi. org/10.1023/A:1004248232450.

Köster, K., F. Berninger, J. Heinonsalo, A. Lindén, E. Köster, H. Ilvesniemi, and J. Pumpanen. 2015. The long-term impact of low-intensity surface fires on litter decomposition and enzyme activities in boreal coniferous forests. International Journal of Wildland Fire 25: 213-223 https://doi.org/ 10.1071/WF14217

Liechty, H.O., and J.J. Hooper. 2016. Long-term effect of periodic fire on nutrient pools and soil chemistry in loblolly-shortleaf pine stands managed with single-tree selection. Forest Ecology and Management 380: 252-260 https:// doi.org/10.1016/j.foreco.2016.08.045.

Lockaby, B.G., J.H. Miller, and R.G. Clawson. 1995. Influences of community composition on biogeochemistry of loblolly pine (Pinus taeda) systems. American Midland Naturalist 134: 176-184 https://doi.org/10.2307/2426494.

MacLean, D.A., and R.W. Wein. 1978. Weight loss and nutrient changes in decomposing litter and forest floor material in New Brunswick forest stands. Canadian Journal of Botany 56: 2730-2749 https://doi.org/10.1139/b78-326.

McKee, W.H., Jr. 1982. Changes in soil fertility following prescribed burning on coastal pine sites, USDA Forest Service Research Paper SE-RP-234. Asheville: USDA Forest Service, Southeast Research Station https://doi. org/10.2737/SE-RP-234

Mellilo, J.M., J.D. Aber, and J.F. Muratore. 1982. Nitrogen and lignin control of hardwood leaf litter dynamics. Ecology 63: 621-626 https://doi.org/10.2307/ 1936780.

Mitchell, R.J., J.K. Hiers, J.J. O'Brien, S.B. Jack, and R.T. Engstrom. 2006. Silviculture that sustains: the nexus between silviculture, frequent prescribed fire, and conservation of biodiversity in longleaf pine forests of the southeastern United States. Canadian Journal of Forest Research 36: 2724-2736 https://doi. org/10.1139/x06-100.

Monleon, V.J., and K. Cromack Jr. 1996. Long-term effects of prescribed underburning on litter decomposition and nutrient release in ponderosa pine stands in central Oregon. Forest Ecology and Management 81: 143-152 https://doi.org/10.1016/0378-1127(95)03658-X.

Olson, J.S. 1963. Energy storage and the balance of producers and decomposers in ecological systems. Ecology 44: 322-331 https://doi.org/10.2307/1932179.

Piatek, K.B., and H.L. Allen. 2001. Are forest floors in mid-rotation stands of loblolly pine (Pinus taeda) a sink for nitrogen and phosphorus? Canadian Journal of Forest Research 31: 1164-1174 https://doi.org/10.1139/x01-049.

Polglase, P.J., N.B. Comford, and E.J. Jokela. 1992. Mineralization of nitrogen and phosphorus from soil organic matter in southern pine plantations. Soil Science Society of America Journal 56: 921-927 https://doi.org/10.2136/ sssaj1992.03615995005600030040x.

Raison, R.J., P.K. Khanna, K.L.S. Jacobsen, J. Romanya, and I. Serrasolses. 2009. Effects of fire on forest nutrient cycles. In: Fire effects on soils and restoration strategies. Volume 5, Land Reconstruction and Management series, ed. A. Cerdà and P.R. Robichaud, 225-256. Enfield: Science Publishers https://doi.org/10. 1201/9781439843338-c8.

Raison, R.J., P.V. Woods, and P.K. Khanna. 1986. Decomposition and accumulation of litter after fire in sub-alpine eucalypt forests. Australian Journal of Ecology 11: 9-19 https://doi.org/10.1111/j.1442-9993.1986.tb00913.x.

Ryan, K.C., E.E. Knapp, and J.M. Varner. 2013. Prescribed fire in North American forests and woodlands; history, current practice, and challenges. Frontier of Ecology and the Environment 11: e15-e24 https://doi.org/10.1890/120329.

Sanchez, F.G. 2001. Loblolly pine needle decomposition and nutrient dynamics as affected by irrigation, fertilization, and substrate quality. Forest Ecology and Management 152: 85-96 https://doi.org/10.1016/S0378-1127(00)00592-2.

Schier, G.A., and K.F. Jensen. 1992. Atmospheric deposition effects on foliar injury and foliar leaching in red spruce. In: The ecology and decline of red spruce in the eastern United States. Ecological studies (analysis and synthesis), volume 96, ed. C. Eager and M.B. Adams, 271-294. New York: Springer-Verlag https://doi. org/10.1007/978-1-4612-2906-3_7.

Schoch, P., and D. Binkley. 1986. Prescribed burning increased nitrogen availability in a mature loblolly pine stand. Forest Ecology and Management 14: 12-22 https://doi.org/10.1016/0378-1127(86)90049-6.

Sluiter, A., B. Hames, R. Ruiz, C. Scarlata, J. Sluiter, D. Templeton, and D. Crocker. 2008. Determination of structural carbohydrates and lignin biomass. Laboratory analytical procedure, National Renewable Energy Laboratory Technical Report NREL/TP-510-42618. Golden: US Department of Energy, Office of Energy \& Renewable Energy, National Renewable Energy Laboratory.

Stanturf, J.A., D.D. Wade, T.A. Waldrop, D.K. Kennard, and G.L. Achtemeier. 2002. Fire in Southern landscapes. In: Southern Forest Resource Assessment, 
ed. D.M. Wear and J. Greis, 607-630. Asheville: USDA Forest Service, Southern Research Station.

Swift, M.J., O.W. Heal, and J.M. Anderson. 1979. Decomposition in terrestrial ecosystems. Berkeley: University of California Press.

Taylor, B.R. and D. Parkinson. 1988. Does repeated freezing and thawing accelerate decay of leaf litter? Soil Biology and Biochemistry 20: 657-665.

Taylor, B.R., D. Parkinson, and W.F.J. Parsons. 1989. Nitrogen and lignin content as predictors of litter decay-rates: a microcosm test. Ecology 70: 97-104 https:// doi.org/10.2307/1938416.

Tian, X.J., S.C. Sun, K.P. Ma, and S.Q. An. 2003. Behavior of carbon and nutrients within two types of leaf litter during 3.5 year decomposition. Act Botanica Sinica 45: 1413-1420.

Tietema, A., and W.W. Wessel. 1994. Microbial activity and leaching during initial oak leaf litter decomposition. Biology and Fertility of Soils 18: $49-54$ https:// doi.org/10.1007/BF00336444.

Trofymow, J.A., T.R. Moore, B. Titus, C. Prescott, I. Morrison, M. Siltanen, S. Smith, J. Fyles, R. Wein, C. Camiré, L. Duschene, L. Kozak, M. Kranabetter, and S. Visser. 2002. Rates of litter decomposition over 6 years in Canadian forests: influence of litter quality and climate. Canadian Journal of Forest Research 32: 789-804 https://doi.org/10.1139/x01-117.

Tukey, H.B., Jr. 1970. Leaching of substances from plants. Annual Review of Plant Physiology 21: 305-324 https://doi.org/10.1146/annurev.pp.21.060170.001513.

Tukey, J.W. 1977. Exploratory data analysis. Reading: Addison-Wesley.

USDA [US Department of Agriculture]. 1979. Soil survey of Ashley County,

Arkansas. USDA Soil Conservation Service and Forest Service in cooperation with Arkansas Agriculture Experiment Station. Washington, D.C.: US Printing Office.

Van Lear, D.H. 2000. Recent advances in the silvicultural use of prescribe fire. In: Fire and forest ecology: innovative silviculture and vegetation management, Tall Timbers Fire Ecology Conference Proceedings, ed. K.W. Moser and C.F. Moser, vol. 21, 183-189.

Williams, R.J., S.W. Hallgren, and G.W.T. Wilson. 2012. Frequency of prescribed burning in an upland oak forest determines soil and litter properties and alters soil microbial community. Forest Ecology and Management 265 241-247 https://doi.org/10.1016/j.foreco.2011.10.032

Zhang, D., D. Hui, Y. Luo, and G. Zhou. 2008. Rates of litter decomposition in terrestrial ecosystems: global patterns and controlling factors. Journal of Plant Ecology 1: 85-93 https://doi.org/10.1093/jpe/rtn002.

\section{Publisher's Note}

Springer Nature remains neutral with regard to jurisdictional claims in published maps and institutional affiliations.

\section{Submit your manuscript to a SpringerOpen ${ }^{\circ}$ journal and benefit from:}

- Convenient online submission

- Rigorous peer review

- Open access: articles freely available online

- High visibility within the field

- Retaining the copyright to your article

Submit your next manuscript at $\boldsymbol{\nabla}$ springeropen.com 